\title{
Vive la France ! Vive la République ! O demokracji we Francji według Henryka Sienkiewicza ${ }^{1}$ Vive la France! Vive la République! About democracy in France according to Henryk Sienkiewicz
}

Streszczenie: Artykuł jest analizą obrazu demokracji francuskiej, jaką przedstawił Henryk Sienkiewicz w swoich listach z Paryża. Pisarz przedstawia ustrój republikański w kategoriach pacyfistycznej utopii, w której swobodnie rozwija się wolna prasa i nauka. Pisarz docenia przede wszystkim możliwość swobodnej wymiany idei politycznych i poglądów naukowych i dlatego też razi go pewien dogmatyzm obecnej literatury francuskiej.

Słowa kluczowe: Sienkiewicz, demokracja francuska, listy z Paryża

O czym pisał Henryk Sienkiewicz w swoich korespondencjach z Paryża? Odpowiedź wbrew pozorom nie jest oczywista: relacje z Wystawy Powszechnej składane albo tuż „przed”, albo tuż „po” tym wydarzeniu sugerują nie tyle grę z czytelnikiem, ile wręcz - otwartą prowokację, która przybiera postać luźnego zbioru paryskich plotek.

Wydaje się jednak, iż zamiar pisarza był znacznie poważniejszy. Hipoteza, jaką proponuję, polega na założeniu, zgodnie z którym autentycznym obiektem fascynacji - a tym samym tematem relacji - był stan francuskiej demokracji, którą Sienkiewicz zamierzał sportretować w najrozmaitszych aspektach. Panoramiczne ujęcie jest zarazem obrazem nakreślonym w sposób ewidentnie

1 Projekt został sfinansowany ze środków Narodowego Centrum Nauki przyznanych na podstawie decyzji numer DEC-2012/06/A/HS2/00252. 
pośredni, objawowy, by tak rzec. Nie ma tu bowiem analizy politycznych mechanizmów, wedle których republika funkcjonuje; są jedynie konkretne przejawy życia codziennego, które odzwierciedlają ów - nieznany wówczas w Europie na taką skalę $e^{2}$ system.

\section{Pacyfizm}

Sienkiewicz nie ma wątpliwości, że demokracja jest jedynym systemem politycznym, który w obecnym momencie dziejowym gwarantuje Francji nie tylko przetrwanie, ale wręcz - dynamiczny rozwój. Przekonanie takie opiera niemal wyłącznie na zasadniczej własności demokratycznych społeczeństw, jaką jest niechęć do wojny i pacyfizm. Streszczając przemówienie ministra handlu z okazji otwarcia wystawy, korespondent donosi:

Rzeczpospolita wychodzi i promieniuje bezpośrednio z narodu, rzeczpospolita jest jego wolnością, jego dobrem, więc nie potrzebuje się wdzięczyć do niego sztucznie, nie potrzebuje schlebiać jego złym instynktom, nie potrzebuje dla podtrzymania popularności rzucać się w wojnę i awantury zagraniczne, nie ma interesów dynastycznych, nie poświęci nigdy interesów kraju dla osoby jakiegoś Lulu czy Frulu, ale z dumą pokazuje światu na wystawie: oto moje dzieło, to dzieło pokoju; te maszyny, te wyroby przemysłu, handlu, te utwory sztuki, to moja i moich dzieci praca. Przeciwnicy moi, co chcieli dać wam? oto zamach stanu, wojnę domową, barykady uliczne, krzyki żołnierskie, huk armat i jęki konających - ja, rzeczpospolita, jako dobra i wielka macierz, wyciągam potężne ręce ponad dziećmi, tulącymi się do mnie, i mówię: błogosławię was, błogosławię tym, którzy pracują, błogosławię pokój czyniących.

Etos demokracji nie ogranicza się zatem do apologii pracy czy podkreślania jej efektu, którym jest wzrastający dobrobyt. Tym zewnętrznym przejawom towarzyszy bowiem rodzaj przemiany wewnętrznej: demokracja stwarza „nowego człowieka": obywatela, który w swoim postępowaniu wyrzeka się form zorganizowanej przemocy. Kwestii tych nie należy zresztą, jak się wydaje, od-

${ }^{2}$ Jak bowiem konkluduje historyk: „Żadne z nich [państw europejskich - C.Z.] nie zaszło w budowie swego ustroju tak daleko na drodze ku demokracji jak Francja. Francja była pierwszą burżuazyjną republika tej epoki” (M. Sobolewski, Od Drugiego Cesarstwa do Piatej Republiki. Z dziejów politycznych Francji 1870-1958, Warszawa 1963, s. 58-59). O politycznych zasadach (między innymi o konstytucji) francuskiej demokracji zob. tamże, s. 55-59 i 64-75. 
dzielać. Demokracja - sugeruje Sienkiewicz - syntetyzuje potrzebę zawodowej aktywności, gromadzenia majątku czy kumulacji kapitału z brakiem namiętności wojennych i zamiłowaniem do pokoju.

Nie wiadomo przy tym, dlaczego tak jest; nie ulega natomiast wątpliwości, że proces ten ma miejsce i że odpowiedzialny jest za niego właśnie ustrój polityczny. Z krytycznych uwag pod adresem Niemiec można bowiem wyciągnąć wniosek, zgodnie z którym uczynienie wojny „zasadą i główną potrzebą bytu” także jest wynikiem porządku państwowego - w tym przypadku monarchicznego. Sienkiewicz przeczuwa zatem, że rola systemu władzy jest tu podstawowa, chociaż nie rozwija tej intuicji. Można tego dokonać w oparciu o dociekania autora bliskiego pisarzowi - Alexisa de Tocqueville. W jego pracy o amerykańskim ustroju niejednokrotnie pojawia się identyczne przekonanie, zgodnie z którym to właśnie demokracja nie sprzyja ani wojnom, ani rewolucjom:

równość możliwości popycha ludzi ku przemysłowym i handlowym karierom, [...] rozwija i różnicuje własność ziemską, [...] wreszcie budzi w człowieku gorące pragnienie dobrobytu. Trudno o instynkty bardziej przeciwne rewolucyjnym namiętnościom. $(611)^{3}$

\section{I znowu:}

Stale rosnąca liczba ceniących spokój właścicieli, rozwój majątków ruchomych, które wojna pochłania tak szybko, łagodność obyczajów i miękkość serca, budzone przez równość odruchy litości, chłodny rozsądek, który czyni człowieka niewrażliwym na wzniosłe i gwałtowne emocje wojennej walki - wszystkie te okoliczności przyczyniają się do upadku wojennego ducha.

Myślę, że można przyjąć za generalną i stałą regułę, iż namiętności wojenne będą rzadziej się pojawiały i będą słabły u narodów cywilizowanych w miarę zrównywania możliwości. (619)

Demokracja stwarza podobne warunki uzyskiwania dobrobytu, który zresztą staje się nie tylko celem, ale i obiektem zasadniczej troski obywatela (szczególnie z klasy średniej). $Z$ tego właśnie powodu wojna jest tak niepożądanym zjawiskiem.

3 W ten sposób odsyłam do: A. de Tocqueville, O demokracji w Ameryce, przeł. B. Janicka i M. Król, Warszawa 2005; cyfra w nawiasie oznacza stronę. 
Z tej perspektywy można, jak się wydaje, odczytać również utopijną wizję ${ }^{4}$, jaką pisarz snuje na kanwie prowadzonych podczas Wystawy Powszechnej obserwacji. Oto bowiem rozmaite stanowiska ekspozycyjne nasuwają następujące skojarzenia:

widać pawilony francuskie, angielskie, tureckie, amerykańskie, greckie, chińskie, włoskie, japońskie, rosyjskie, mauretańskie, stojące tuż obok siebie, nad domami widać flagi pływające w powietrzu, a przed domami narodowości wszystkich pięciu części świata, wrogie często między sobą, gdy każda jest u siebie, a tu przyjazne, zbliżone i powiązane ze sobą wielkim świętem cywilizacji. Patrząc na to wszystko, patrząc na to przekonanie głębokie o wyższości zgody, o słodyczy owoców pokoju i cywilizacji, o wielkim znaczeniu ludzkości, patrząc na to przejęcie się swą cywilizacyjną rolą, jakie zdaje się wiać od tych tłumów, na chwilę prawie przychodzi zwątpić, czy wobec takiego rozwoju pojęć ogólnie ludzkich wojna, rzezie, hurtowne zabijanie się, pożogi miast i wiosek jeszcze są możliwe w dzisiejszych czasach.

Złudzenie to, któremu oprzeć się niepodobna, stanowi największy urok tego miasta narodów, najprzyjemniejsze i najoryginalniejsze wrażenie, jakie czyni wystawa.

Znowu zatem powraca koncepcja pokojowej koegzystencji, tyle że teraz rozszerzona zostaje o skalę międzynarodową. W tym obrazie nie ma już ani mocarstw, ani kolonii, ani państw pozbawionych znaczenia. To ujednolicenie zakłada ową demokratyczną równość szans (bez niwelacji jednostkowej odmienności), w obrębie której odbywają wzajemne kontakty. Abstrahując od podkreślanego tutaj kontekstu świątecznego, można - biorąc sytuację wystawy dosłownie - sformułować podstawowe przekonanie: oto demokracja dlatego zapewnia pokój, iż wymaga takiej wzajemności, która ma charakter pozytywny, dobroczynny. Wymiana, do jakiej predestynuje, przypomina więc handel (a nie wojnę): jest oddawaniem tego, co najlepsze i zarazem otrzymywaniem równie wartościowych obiektów.

${ }^{4}$ Ma ona znamiona tego, co Jerzy Szacki określił mianem tak zwanej utopii czasu, w których idealny świat staje się domeną przyszłości (zob. J. Szacki, Spotkania z utopia, Warszawa 2000, s. $48-52)$. 


\section{Prasa}

Relacjonując paryskie wydarzenia Sienkiewicz parokrotnie odwołuje się do prasowych polemik, jakie poruszały i angażowały ówczesną opinię publiczną. Partyjny pluralizm - a przynajmniej dwubiegunowy (to znaczy monarchistyczny i republikański) podział sceny politycznej - zakłada istnienie organów prasowych, których celem jest propagowanie określonych stanowisk.

Już samo funkcjonowanie tego mechanizmu musiało na młodym dziennikarzu, który wychowany został w warunkach restrykcyjnej cenzury, sprawić niemałe wrażenie. W przeciwnym wypadku owe „incydenty prasowe” - których znaczenie było raczej nikłe - zostałby przemilczane. Jednakże Sienkiewicz zajmuje się nimi po pierwsze dlatego, że zamierza skompromitować monarchistów, obnażając nieracjonalny tryb ich argumentacji. Prasa rojalistyczna używa przede wszystkim strategii pretekstowej: nie mogąc zupełnie zdyskredytować danego wydarzenia - na przykład Wystawy Powszechnej czy jubileuszu Voltaire'a - wynajduje w nich drobne, nieistotne mankamenty, które następnie zostają nieproporcjonalnie wyolbrzymione. Nie wyklucza to sytuacji, w której pojawia się frontalny atak (na przykład na instytucję loterii) mający udowodnić, iż ewentualne skutki dobroczynne są znacznie skromniejsze od poważnych zagrożeń, jakie zapewne będą tu miały miejsce.

Wykazywanie tego typu retorycznych uproszczeń nie wydaje się jednak najważniejsze. Pisarz referuje je, gdyż - po drugie - dzięki temu może umieścić siebie w centrum sporu: w obszarze polemos, który jest naturalnym żywiołem prasy w demokratycznym społeczeństwie. I wbrew pozorom kwestia ta nie dotyczy wyłącznie periodyków opozycyjnych, chociaż to z nich właśnie korespondent czerpie podawane przykłady. Kiedy jednak formułuje generalną diagnozę, stwierdza, iż:

masy zasadę: „republika to naród nie partia”, zrozumiały lepiej, niż ich rzecznicy i dzienniki. Rzecznicy i dzienniki wrzeszczą jeszcze czasem, jak demagogowie masy zaś, wybierając spokojnie republikańskich deputowanych, zdają się mówić: - Dajcie pokój! nie potrzebujemy krzyczeć, skoro mamy dość sił, aby działać.

Sienkiewicz potwierdza tym samym diagnozę Tocqueville’a, który upolitycznienie uważał za fundamentalną zasadę prasy:

We Francji ogłoszenia handlowe zajmują niewiele miejsca i nawet wiadomości są nieliczne. Najżywsze strony gazety to te, które poświęcone są dyskusjom politycznym. [...] Esprit de corps dziennikarzy we Francji polega na gwałtownym, aczkolwiek dystyngowanym i elokwentnym dyskutowaniu spraw państwa. (165 i 166). 
Pisarz zresztą dodatkowo podkreśla tę zasadę. Sugeruje bowiem, iż działa ona niejako samoczynnie, czyli że jej związek z praktyką demokratycznej władzy nie tylko nie jest ścisły, ale wręcz bywa akcydentalny. Prasa jako teren ostrych (niekiedy posługujących się niewybrednymi środkami) sporów dotyczących polis staje się domeną do pewnego stopnia autonomiczną. Nawet jeśli publiczna debata wywiera w demokracji wpływ na określone rozstrzygnięcia, to Sienkiewicz - zapewne dzięki amerykańskim doświadczeniom - natychmiast zauważa ukrytą słabość mechanizmu, w którym demagogia (prasa republikańska) ${ }^{5}$ czy „krytyka dla krytyki” (prasa opozycyjna) także odgrywają niemałą rolę. Nic tak bowiem nie zaspokaja skłonności do walki z politycznym oponentem, jak ten rodzaj ekspresji, którą umożliwia i zapewnia wolna prasa.

\section{Nauka}

W ostatnim liście z Paryża Sienkiewicz koncentruje się na zagadnieniach dotyczących kultury umysłowej. Cechą charakterystyczną stołecznego środowiska jest brak izolacji między działalnością uczonych a szerszymi kręgami obywateli, którzy wykazują niemałe zainteresowanie aktualnymi osiągnięciami badawczymi. Korespondent stwierdza:

Jest to może charakterystyczna cecha Francji i Paryża, że tu uczeni nie stanowili nigdy, na kształt średniowiecznych Różokrzyżowców, bractw zamkniętych. Mszę przy ołtarzu nauki odprawiają wprawdzie tylko kapłani, ale słucha owej mszy cała publiczność. (...) Takie popularyzowanie nauki, takie dopuszczanie z pomocą Sorbony, Collège de France i innych zakładów szerszej publiczności do udziału w ruchu naukowym, a nawet i sądu o nim, sprawia, że nauka i płynące z niej nowe idee nie są tu niczym pergaminowym, zżółkłem, zwiędłym, jakąś wyłączną arendą uczonych profesorów, ale czymś żywym, wchodzącym natychmiast w krew i cały organizm ogółu.

Temu to może przypisać należy, że lud ten, nie składający się przecież z jednostek bezwarunkowo najbystrzejszych i najwięcej umysłowo uzdolnionych, wiedzie jednak poniekąd rej cywilizacyjny i daje początkowanie wszelkim nowym ideom. Nie twierdzę, że powód to wyłączny, ale zapewne jeden z wielu. Nowe idee wytwarzane bywają przez uczonych lub przez społeczne warunki, ale odczuwa je i daje im popęd lud; lud zaś może je tym łatwiej i potężniej odczuwać, im szerszą drogą go dochodzą.

${ }^{5}$ Pamiętać jednak należy, iż w ocenie pisarza prasa republikańska odznacza się wyższym poziomem merytorycznych dyskusji. Ponadto charakteryzuje ją - jak i samą demokrację - pewna doza autokrytycyzmu, czego zupełnie pozbawione są organy rojalistyczne czy cesarskie. 
Nawet jeśli Sienkiewicz przekonuje tutaj, iż porządek idei (najprawdopodobniej pozostający w zakresie tak zwanych nauk o człowieku) nie może mieć charakteru elitarnego, to i tak kluczowe pozostają założenia, dzięki którym egalitarny status prądów intelektualnych jest aż tak prawdopodobny. Okazuje się zatem, że człowiek demokracji nie jest niewolnikiem pracy, a zapewnienie podstaw egzystencji jest dla niego warunkiem tyleż niezbędnym, ile - niewystarczającym. $Z$ tego też powodu powstają określone rozwiązania systemowe: państwo oferuje obywatelom zinstytucjonalizowane formy kontaktu z najnowszymi propozycjami intelektualnymi. W ten sposób wytwarza się swoista cyrkulacja idei, które opuszczają swoje źródło, rozprzestrzeniają się w obrębie społeczeństwa, a niekiedy zapewne wracają do punktu wyjścia - obdarzone nabytymi ocenami czy nawet modyfikacjami.

Opisanie tej trajektorii nie stało się dla pisarza priorytetem. Ważniejsze jest tu nastawienie funkcjonalne: rozprzestrzenianie określonych stanowisk służy przede wszystkim im samym, gdyż włączone w publiczną debatę tracą ściśle abstrakcyjny charakter i są "testowane", poddawane konfrontacji z rozmaitymi aspektami rzeczywistości. Z drugiej strony Sienkiewicz nie zapomina o wpływie tej procedury na tych, którzy jej dokonują. Kiedy zatem przedstawia on przyczyny, z powodu których słuchacze tak licznie gromadzą się na wykładach w Collège de France, stwierdza:

Stąd ten żywy interes i gorączkowa ciekawość publiczności, która przychodzi tam po sprawdzanie własnych przekonań, po utwierdzenie się w sądach i estetycznych instynktach. Czy istnieje, a jeśli istnieje, to zdrowyż li kierunek obecny? dokąd idziemy? gdzie i jaka jest synteza dzisiejszych objawów twórczości, tak rozmaitych i rozstrzelonych, że zwykłe oko widzi na nich raczej chaos i rozprzężenie? Co usłyszymy i co nam powiedzą? czy pozwolą czcić dotychczasowe bóstwa, czy może zapadnie wyrok, jaki kiedyś Klodwig usłyszał: „Sigambrze, pal, coś czcił, a czcij, coś palił”?

Odbiorcy zyskują zatem nie tylko orientację, ale wręcz rodzaj kulturowej samoświadomości. Kontakt z wiedzą - w tym przypadku o literaturze - pozwala na rozpoznanie aktualnych zjawisk działających w domenie cywilizacyjnej, i na zajęcie wobec nich własnego stanowiska. Jeśli tak, to sama nauka staje się tu czymś więcej: Sienkiewicz nie bez powodu bowiem sięga po sakralne metafory, sugerując, iż ten rodzaj kompetencji kulturowej przejął w laickim społeczeństwie dawną rolę religii.

Warto także zwrócić uwagę na fakt, iż niezależnie od przebiegu owej interakcji - pisarz raz skłania się ku autorytarnemu monologowi, raz ku dialogicznej negocjacji - jej istota zawsze polega na hierarchizacji (lub rehierarchizacji) i na nieuchronnym w takich sytuacjach wartościowaniu. Oznacza to, że porządek 
idei (zwłaszcza kulturowych) nie tworzy statycznej struktury, ale oparty jest na stałej migracji między pozycjami centralnymi i peryferyjnymi. Żeby tak było, potrzebny jest pierwiastek sporu czy krytycznego nastawienia, dzięki któremu zmiana jest możliwa. Jego istnienie Sienkiewicz przyjmuje implicite i raczej nie wydobywa go z cienia. Jednakże kiedy wspomina o dziełach Hipolita Taine’a i Ernesta Renana, w których „źródło” republiki (to znaczy Rewolucja Francuska) poddane zostało druzgocącej krytyce, pokazuje w działaniu ów mechanizm przemieszczenia. Trudno zresztą oprzeć się wrażeniu, że demonstracja ta ma charakter czysto pokazowy: oto demokracja okazuje się systemem do tego stopnia otwartym, iż dopuszcza nawet atak na własną genezę. W wolnym ustroju przepływ idei także musi być swobodny, nawet jeśli ten „ruch” mógłby się wydać zbyt niekontrolowany.

\section{Literatura}

Nie jest oczywisty powód, dla którego Sienkiewicz nakreśliwszy rolę Collège de France przechodzi do omówienia aktualnie odbywających się tam wykładów z historii literatury francuskiej, które prowadził Paul Albert. Korespondent streszcza bowiem - i to w sposób raczej pobieżny ${ }^{6}$ - zaledwie jeden, inauguracyjny wykład, a następnie - przechodzi do własnych rozważań nad historycznym rozwojem nurtów artystycznych. Młody dziennikarz zastępuje więc uczonego profesora; i nie ulega wątpliwości, że zaproponowany porządek będzie inny i zostanie opatrzony autorską sygnaturą.

Jej pierwszym przejawem jest analiza porównawcza romantyzmu francuskiego i polskiego (a nawet szerzej - słowiańskiego). Oba nurty zamierzały uzyskać hegemonię na literackiej scenie w dość podobny sposób: przez kreatywną adaptację odległych tradycji kulturowych, które miały dostarczyć tematów, środków wyrazu i tym podobne. Mankamentem romantyzmu francuskiego, na który pisarz wyraźnie zwraca uwagę, było dokonanie nietrafnego wyboru; nietrafnego, czyli - upraszczając - zbyt elitarnego, nie-demokratycznego. Romantyzm polski sięgnął do przekazów ludowych, wprowadzając tym samym do literatury jakości nowe i oryginalne (między innymi animizm, mistycyzm, swoisty patriotyzm). Romantyzm francuski pozostxał zafascynowany kulturą średniowiecza, dlatego stworzył dzieła nie tylko zbyt sztuczne i konwencjonalne, ale i zbyt nowoczesne,

${ }^{6}$ Można się o tym przekonać, czytając opublikowaną wersję wykładów Alberta z Collège de France (zob. P. Albert, La littérature française au dix-neuvième siècle, Tome I, Les origines du romantisme, Paris 1882, s. 19-26). 
to znaczy oparte na procesie alienacji wybitnej jednostki. I nawet jeśli Sienkiewicz zauważa, że polskiemu romantyzmowi także przydarzało się mechaniczne powielanie ludowych schematów, to jednak ów „potworny rozrost własnego 〉>ja«" był tu nieznany.

Niezależnie od trafności tych diagnoz ich motywacja nie ulega wątpliwości. Pisarz pragnie usunąć ze współczesnej liryki ów „wybujały egotyzm tak zwanych dusz dzikich”, który okazał się kłopotliwym spadkiem po romantyzmie. Dlatego jedynym remedium pozostaje zwrot w kierunku innego modelu kultury: w kierunku wyobraźni zbiorowej, która w sposób nieskażony przechowuje to, co najważniejsze (i jeszcze przednowoczesne) dla danego narodu czy wspólnoty.

Taką diagnozę Sienkiewicz stawia poezji, ponieważ proza francuska już jej nie wymaga, zważywszy na jej aktualny kierunek rozwoju, który nosił miano naturalizmu. Okazuje się jednak, że jednoznaczne i klarowne rozpoznania w domenie liryki nie znajdują odpowiednika w dziedzinie epickiej. Trudno bowiem stwierdzić, jaki - już wtedy - był stosunek pisarza do naturalizmu; trudno wręcz oprzeć się wrażeniu - zwłaszcza analizując linię argumentacyjną - że żaden istotny pogląd nie został tu jeszcze wykrystalizowany, a zamiast niego pojawia się zbiór luźnych, niekoniecznie koherentnych uwag. Zaskakuje tu zresztą analogiczne podejście, które pojawiło się w przypadku romantycznej liryki. Obie te formacje widziane są przez Sienkiewicza z perspektywy historycznego rozwoju literatury i dlatego w danym momencie są niezbędnym etapem owej ewolucji; etapem, który wszakże z definicji domaga się przezwyciężenia czy przeobrażenia w zupełnie inny kierunek.

Najbardziej interesującym fragmentem są tu rozważania, w których kwestia naturalizmu analizowana jest na konkretnym przykładzie. Celem tego exemplum jest udowodnienie tezy, zgodnie z którą naturalizm nie jest już nawet realizmem, ale czymś „poniżej”: reprezentacją tego, co banalne, nudne, „bardziej powszednie niż życie samo”. Do takiego bowiem wniosku doprowadzają Sienkiewicza dociekania nad najbardziej popularnym schematem fabularnym francuskiej powieści, którym jest romans. Jego obecność nie wzbudza wątpliwości natury moralnej, ale - psychologicznej. Pisarz zarzuca powieści francuskiej posługiwanie się statyczną strukturą małżeńskiego trójkąta: romans między żoną a kochankiem toczy się bowiem w ukryciu, a po okresie względnej stabilizacji zmierza do samoistnego końca. Natomiast według Sienkiewicza tego typu relacja powinna prowadzić do zerwania dawnego małżeństwa i stworzenia nowego związku:

Jeśli się komu zdarzy szczęście rozkochać kobietę, a nieszczęście, że ta kobieta jest cudzą żoną, uczciwiej zapewne robi i prawdziwiej kocha, gdy, zajrzawszy mężowi w białka oczu, powiada mu: kocham pańską żonę, zatem nie mogę być pańskim 
przyjacielem! Miłość idzie wtedy na cenę życia, zatem jest uczuciem prawdziwie drogim, silnym, jak burza, zatem usprawiedliwiającym. Mniejsza, jak się dramat skończy, ale dramat dramatem. Że jednak w życiu tak się nie dzieje, że wygodniej jest kochać się w sekrecie, potem się sobie sprzykrzyć i pójść „każde w swoją drogę” bez hałaśliwych zajść z mężem, że to się częściej zdarza, a przeciwne postępowanie byłoby egzaltacją, więc powieść francuska realna przyjmuje tylko romans, pisuje i wysławia tylko romans.

Nie ulega wątpliwości, iż Sienkiewicz wskazuje tu na zbyt duże uzależnienie fabularyzacji romansu od realnych obserwacji. W innym miejscu stwierdził dobitnie, iż w naturalistycznej szkole:

Fantazja poszła w niej już nie tylko pod straż prawdopodobieństwa i prawdy, ale, po prostu, rzeczywistości.

Takie nastawienie nie pozwala jednak na przekształcenie wiarygodnych danych w dzieło literackiej sztuki. Sienkiewicz nie precyzuje tej kwestii, ale trzymając się powyższego przykładu można by pokusić się o dopowiedzenie. Podstawowa sugestia jest jasna: jeśli już autor decyduje się na taki schemat, to musi z romansu uczynić dramat. Na czym miałoby to polegać? Zamiast „pokojowego" finału potrzebny jest konflikt - i to najlepiej podwójny: zarówno psychologiczny, jak i ideowy. Tego typu konstrukcja wymaga bowiem napięć między dwoma rywalami, a być może także - przemocy (a nawet śmierci). Każdy $\mathrm{z}$ antagonistów będzie powoływał się na własne racje (na przykład miłości czy małżeństwa), więc przeniesienie sporu na poziom ideologiczny, światopoglądowy byłoby wręcz naturalne.

Tego wszystkiego, jak się wydaje, brakuje w najpopularniejszym wariancie francuskiej powieści, dlatego pisarz radzi zupełną rezygnację z tego typu pomysłów. Zamiast nich - pozostając przy tej samej metodzie kreacyjnej - należałoby raczej skoncentrować się na prezentacji tego, co dzieje się w demokratycznym społeczeństwie. W nim zresztą już istnieje:

jakieś instynktowne poczucie potrzeby, aby cała literatura piękna, zatem cała literatura twórcza, weszła na inne drogi, wzięła rozbrat ze zdziczałym egotyzmem, $\mathrm{z}$ romansem, a wsiąknęła w siebie nowe myśli i nowe idee, wielkie a godne odradzającego się narodu. Tyle przecie nowych pojęć politycznych i filozoficznych krąży w powietrzu. Pojmuje je rozum i stąd rodzi się nauka, ale odczuwa serce i z tych uczuć może wykwitnąć odrodzona literatura. 
Trudno jednak tej recepty nie ujmować w kontekście wcześniejszych rozważań o funkcjonowaniu we francuskiej republice prasy, polityki i nauki. Przy takim założeniu okazuje się, że owa cyrkulacja idei - która ma stać celem literackich zabiegów - jest oparta na nieustannych rekonfiguracjach, rehierarchizacjach czy przewartościowaniach. Implicite pojawia się tu zatem pierwiastek sporu i polemiki; pierwiastek, bez którego nie istnieje nie tylko republikańska sfera publiczna, ale i tworzona $\mathrm{z}$ jej inspiracji literatura. $\mathrm{Z}$ pewnym przybliżeniem można stwierdzić, iż Sienkiewicz znów pozostaje tu uczniem Tocqueville’a, który o sztuce w czasach demokracji pisał:

Literaturą tą będzie rządzić myśl o dzikiej, prymitywnej niemal sile, a jej owoce będą liczne i różnorodne. Pisarze zechcą raczej zadziwiać, niż się podobać, i raczej rozbudzać namiętności, niż oczarowywać poczucie smaku. (445)

\section{Wnioski}

Dość łatwo można teraz w Sienkiewiczowskim opisie francuskiej demokracji dostrzec zasadniczą linię podziału. Przebiega ona między obszarem kultury materialnej i umysłowej. Ta druga sfera jest zresztą w interesujący sposób niejednorodna. Pisarz zastosował tu swoisty trójpodział, któremu odpowiada spadek afirmatywnego nastawienia. Największą fascynację wzbudza w nim funkcjonowanie wolnej prasy, nieco mniejszą - nauki, natomiast najwięcej zastrzeżeń pojawia się pod adresem literatury. Dwa parametry podlegają tu zmianie: zakres adresatów czy uczestników biorących udział w tych przejawach kulturowej egzystencji oraz obecny w niej - w sposób jawny lub ukryty - poziom ideowego sporu. W aktualnej literaturze francuskiej oba te współczynniki są raczej niskie, dlatego zmiany - wiązane zresztą z twórczością Emila Zoli - są tu tak konieczne.

Kłopot tego ujęcia polega oczywiście na tym, że ów pierwiastek polemiczny powinien podlegać ścisłej kontroli. Apologia republiki, z jaką występuje tu Sienkiewicz, polega $w$ istocie na tym, że zapewnia ona wszystkim obywatelom trwały pokój, dzięki któremu efektywna praca prowadzi do kumulacji kapitału i wzrastającego dobrobytu. Trudno jest zresztą oprzeć się wrażeniu, że to nie tyle sam system polityczny, ile jego konkretne przedsięwzięcie wywarło większy wpływ na pisarza. Na poziome tematyzacji bezpośredniej paryska Wystawa Powszechna z 1878 r. jest - paradoksalnie - „wielkim nieobecnym” tej korespondencji; dopiero uwagi o republikańskim pacyfizmie nasuwają wniosek, iż światowa ekspozycja funkcjonuje tu niczym model, który z ukrycia dokonuje odpowiedniej strukturyzacji. Demokrację francuską Sienkiewicz wyobraża sobie 
dokładnie na wzór zwiedzanej wystawy, w której praca i jej efekty są jedynym obiektem podlegającym dobroczynnej wymianie.

Francuski system ustrojowy - z jednej strony - zapewnia więc pokojowy ład, dzięki któremu wzrastają zlecenia i poziom konsumpcji; z drugiej natomiast umożliwia prowadzenie namiętnych sporów politycznych lub intelektualnych. W tym podziale nie byłoby nic nadzwyczajnego, gdyby nie fakt, iż Sienkiewicz ewidentnie zakłada szczelną (i - dodajmy - obustronną) separację między tymi sferami. W demokracji wszelki konflikt musi zatem pozostać na poziomie idei i poglądów a jakiekolwiek przeniesienie go w obszar faktycznych relacji, grozi prawdziwym „dramatem”, od którego nie bez powodu stronią francuscy pisarze.

\section{Bibliografia}

1. Albert P., La littérature française au dix-neuvième siècle, Tome I, Les origines du romantisme, Paris 1882.

2. de Tocqueville A., O demokracji w Ameryce, przeł. B. Janicka i M. Król, Warszawa 2005.

3. Sobolewski M., Od Drugiego Cesarstwa do Piatej Republiki. Z dziejów politycznych Francji 1870-1958, Warszawa 1963.

4. J. Szacki, Spotkania z utopia, Warszawa 2000, s. 48-52.

Summary: The article is an analysis of the image of French democracy presented by Henryk Sienkiewicz in his letters from Paris. The writer presents the republican system in terms of pacifist utopia, in which free press and science freely develops. The writer appreciates, first of all, the possibility of free exchange of political ideas and scientific views, and therefore he is offended by a certain dogmatism of present French literature.

Keywords: Sienkiewicz, democracy, letters from Paris 